\title{
Food insecurity and socioeconomic, food and nutrition profile of schoolchildren living in urban and rural areas of Picos, Piauí
}

\author{
Insegurança alimentar e perfil socioeconômico, \\ alimentar e nutricional de escolares de áreas \\ urbana e rural do municipio de Picos, Piauí
}

Jailane de Souza AQUINO'

Leopoldina Augusta Souza SEQUEIRA-DE-ANDRADE²

Patrícia Elaine Bellini Alencar da SILVA ${ }^{3}$

Alciene Pacheco da SILVA ${ }^{3}$

Cid Rangel de Sousa VIEIRA ${ }^{3}$

Pedro Israel Cabral de LIRA ${ }^{2}$

A B S T R A C T

\section{Objective}

This study aimed to determine the prevalence of food insecurity among schoolchildren living in urban and rural areas of Picos, Piaui associated with the socioeconomic profile of families and their food intake and nutritional status.

\section{Methods}

Study participants were families with children aged 7-10 years enrolled in municipal schools, totaling 342 families/schoolchildren. The study was conducted at school facilities through interviews with mothers - or guardians - using a questionnaire based on the Brazilian Food Insecurity Scale and socioeconomic variables and food frequency questionnaire. The nutritional status of children was assessed using the following indexes: weight/age, height/age and body mass index/age.

\section{Results}

The prevalence of food insecurity was high and similar for rural and urban areas, $84.3 \%$ and $83.3 \%$, respectively. In general, lower income and consumption of untreated water was associated with greater frequency of food

${ }^{1}$ Universidade Federal da Paraíba, Centro de Ciências da Saúde, Departamento de Nutrição. Campus I, Cidade Universitária, s/n., Castelo Branco, 58059-900, João Pessoa, PB, Brasil. Correspondência para/Correspondence to: JS AQUINO. E-mail: <lalaaquino@hotmail.com>.

2 Universidade Federal de Pernambuco, Centro de Ciências da Saúde, Departamento de Nutrição. Recife, PE, Brasil.

${ }^{3}$ Universidade Federal do Piauí, Centro de Ciências da Saúde, Departamento de Nutrição. Picos, PI, Brasil. 
insecurity $(p \leq 0.01)$. In urban areas, higher percentage of food insecurity was associated to lower educational levels $(p \leq 0.05)$. Dietary intake and nutritional status of schoolchildren were not associated with food insecurity condition of families.

\section{Conclusion}

The percentage of families at food insecurity, as well as the food consumption and nutritional status of schoolchildren were similar between urban and rural areas, characterized as a homogeneous population in terms of socioeconomic conditions.

Indexing terms: Food consumption. Food security. Nutritional status. Socioeconomic indicators.

\section{RE S U M O}

\section{Objetivo}

Determinar a prevalência de insegurança alimentar em famílias com escolares de áreas urbana e rural do município de Picos, Piauí, relacionando-a com o perfil socioeconômico das famílias, com o consumo alimentar e o estado nutricional dos escolares.

\section{Métodos}

Participaram do estudo famílias com escolares entre 7 e 10 anos matriculados na rede municipal de ensino, totalizando 342 famílias/escolares. O estudo foi conduzido na própria escola, mediante entrevista com as mães ou responsáveis, utilizando-se questionários baseados na Escala Brasileira de Insegurança Alimentar e variáveis socioeconômicas das famílias e de frequência alimentar dos escolares. O estado nutricional dos escolares foi avaliado quanto aos índices: pesol idade, altura/idade e índice de massa corporallidade.

\section{Resultados}

A prevalência de insegurança alimentar foi elevada e similar para as áreas rural e urbana: 84,3\% e 83,3\% respectivamente. No geral, a menor renda familiar e o consumo de água sem tratamento estiveram associados à maior frequência de insegurança alimentar $(p \leq 0,01)$. Na área urbana, observa-se um maior percentual de insegurança alimentar para os menores níveis de escolaridade $(p \leq 0,05)$. O consumo alimentar e o perfil nutricional dos escolares não estiveram associados à condição de insegurança alimentar de suas famílias.

\section{Conclusão}

O percentual de famílias em insegurança alimentar bem como o perfil de consumo alimentar e nutricional dos escolares foram similares entre as áreas urbana e rural, caracterizando-se como uma população homogênea quanto às condições socioeconômicas.

Termos de indexação: Consumo de alimentos. Segurança alimentar e nutricional. Estado nutricional. Indicadores socioeconômicos.

\section{NTROD UCTIO N}

Food and nutrition security is defined as "the everyone's right to regular and permanent access to quality food in sufficient quantity, without compromising access to other essential needs based on health-promoting food practices that respect cultural diversity and are socially, economically and environmentally sustainable"1 (p.15). This condition must be ensured in a context of full access to other fundamental rights such as education, housing, health and social welfare within an autonomous and sustainable development process based on the exercise of ethical and culturally acceptable labor activity².

Food insecurity can be measured through food and nutrition surveillance, food intake surveys and local information systems. Food insecurity also involves important psychosocial components such the concern or uncertainty of whether or not there will be food next month ${ }^{3}$.

The Escala Brasileira de Insegurança Alimentar (EBIA, Brazilian Food Insecurity Scale) is a quantitative instrument widely used to estimate the prevalence of various levels of food 
insecurity in groups or populations at risk at local, regional or national levels ${ }^{4}$. Children are the population group most vulnerable to food insecurity, since the nutritional consequences are more immediate and serious, and also because, when a child has nutritional problems due to dietary deficiency, it could be inferred that adults in the household have been feeding insufficiently for some period of time ${ }^{5}$.

From the nutritional point of view, there is no doubt about the importance of proper nutrition to ensure growth and development, especially during childhood, and in adulthood, proper nutrition plays the role of promoting and maintaining health and well-being. When submitted to severe dietary restrictions, children are exposed to nutritional deficiencies and exhibit poor growth conditions, contributing to increased vulnerability to infections and deficiencies in the maturation of the nervous system and mental and intellectual development, causing morphological and functional imbalances which, depending on intensity and duration, may be irreversible ${ }^{6}$.

Few studies have addressed the association between food insecurity and place of residence ${ }^{7-9}$. Some studies have provided explanations for spatial variations and access to food, and reported that residents in urban areas have greater access to goods and services essential for health maintenance than residents of rural areas ${ }^{10}$. However, in a study conducted in the state of Amazonas, the forms of food insecurity showed a trend of lower prevalence in rural areas (68.7\%) when compared with urban area of Manaus (AM), (89.1\%), especially the severe form of food insecurity, with $28.2 \%$ in rural areas compared to $44.6 \%$ in urban areas $^{11}$.

In this context, the aim of this study was to determine the prevalence of food insecurity among schoolchildren living in urban and rural areas of Picos (PI), relating it to the socioeconomic profile of families, as well as the food consumption and nutritional status of schoolchildren.

\section{METHODS}

This is a cross-sectional study including families with children aged 7-10 years. The sample size was calculated based on the universe of 4,398 children in the age group of interest enrolled in 64 municipal schools in urban and rural areas of Picos (PI), adopting a significance level of $95 \%$ for a prevalence of $20 \%$ of moderate and severe food insecurity, average value found for the state of Piaui ${ }^{12}$, with a sampling error of $\pm 4.5 \%$ (Epi-Info version 6.04b), taking into account a loss of approximately 20\%, totaling 342 students/ families with sample representativeness for the municipality. This municipality has population of 73,414 inhabitants and area of $534.715 \mathrm{~km}^{2}$ and is located $330 \mathrm{~km}$ away from the state capital ${ }^{13}$.

Municipal schools were selected according to areas enclosed by the Department of Education of Picos (PI). For data collection, students' parents were called and those who agreed to participate in the study signed the Informed Consent Form. The study was approved by the Ethics Committee on Human Research of the Universidade Federal do Piauí ( $n^{\circ}$ 0176.0.045.000-08). The team of interviewers was previously trained for the application of questionnaires and data collection was carried out from August 2009 to February 2010. Initially, the socioeconomic questionnaire was applied to parents or guardians, containing variables such as family income, living conditions (sewage service, garbage collection, access to treated water, etc.), educational level and participation in government income transfer programs.

Perception of food insecurity was assessed by interviewing parents or guardians using a questionnaire based on the EBIA, which consists of 15 closed questions (yes or no) on food insufficiency experience in the last three months at various levels of intensity, ranging from the concern that food may be lacking until the experience of spending a whole day without eating. Of the 15 questions, seven refer to family members under 18 years of age. Each affirmative 
response to the food insecurity questionnaire scores 1 point, and the sum is the scale score, ranging from 0 to 15 points as follows: security 0 ; mild insecurity 1-5 points; moderate insecurity 6-10 points and severe insecurity 11-15 points in families with children under 18 years of age ${ }^{14}$.

The Food Frequency Questionnaire was also applied to parents or guardians as an interview, assessing the consumption of 54 foods, divided into the following groups: cereals, pasta, legumes, fruits, eggs, vegetables, roots and tubers, meats, dairy products, sweets and fats. The consumption frequency was classified as "rarely", "less than once a month", "from one to three times a month," "once a week", "from two to four times a week", "once a day", "two or more times a day. "Rarely" was defined as occasional consumption or no consumption ${ }^{15}$.

To assess the nutritional status, weight and height were measured by trained Nutrition students. For weight, Tanita digital scale (São Paulo, Brazil) with capacity of up to $150 \mathrm{~kg}$ and $100 \mathrm{~g}$ precision was used, and children were weighed barefoot and with minimal clothing. Height was measured with the use of measuring tape adhered to wall without footers and a wooden square, according to recommendations of Lohman et al. ${ }^{16}$. For this measure, the tape was attached to the wall and children were placed upright, barefoot, with upper limbs along the body and heels, back and head touching the wall. Children were classified according to their nutritional status as recommended by World Health Organization (WHO ${ }^{17}$, using the Height/ Age (H/A), Weight/Age (W/A) and Body Mass Index/Age (BMI/A) ratios. Children with Z-scores greater than 2.0 above the median of the reference population were considered obese; overweight with Z-score greater than 1.0 above the median of the reference population and low weight those with Z-scores 2.0 below the median of the reference population. Children with Z-scores below 2.0 were considered with growth deficit.

For analysis of the anthropometric data, the Anthro-Plus software version 3.2.2 was used.
To verify the existence of association between place of residence according to food insecurity (outcome variable) and socioeconomic and anthropometric variables and dietary intake (independent variables), the Chi-square test was used, adopting significance level of $p \leq 0.05$. The Epi Info software version $6.04 \mathrm{~b}$ was used for analyses.

\section{R E S U L T S}

Figure 1 shows that the prevalence of food insecurity was high and similar for rural and urban areas (84.3\% and $83.3 \%$, respectively), and moderate and severe food insecurity values were 38 9\% and $38.2 \%$, respectively.

Table 1 shows that for the entire sample $(n=342)$, in families with lower income, there is a higher prevalence of food insecurity ( $p \leq 0.01)$, with similar behavior among families living in rural and urban areas. Regarding the educational level of the family head, there is a higher percentage of food insecurity for the lowest educational levels, especially illiterates, only in the urban area $(p \leq 0.05)$.

Consumption of treated water was associated with lower frequency of food

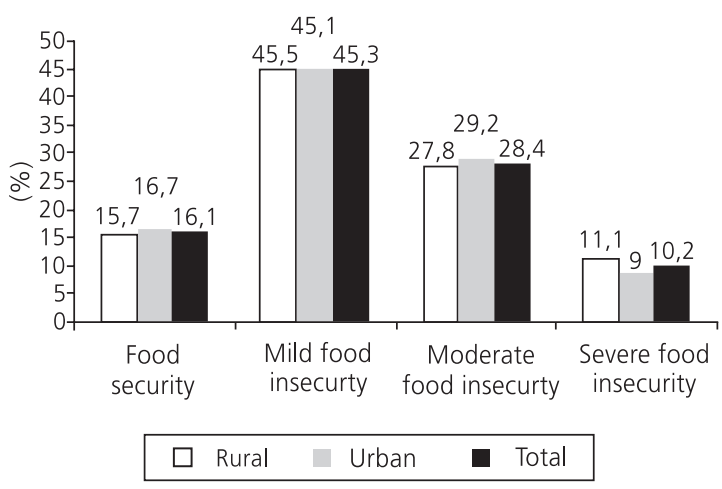

Figure 1. Food insecurity classification of schoolchildren living in urban and rural areas of the city of Picos (PI), 2009. Note: $p<0.05$. 
Table 1. Food insecurity classification according to the socioeconomic characteristics and housing conditions of families with schoolchildren living in urban and rural areas of the city of Picos (PI), 2009.

\begin{tabular}{|c|c|c|c|c|c|c|c|c|c|}
\hline \multirow{2}{*}{ Variables } & \multicolumn{3}{|c|}{ Total } & \multicolumn{3}{|c|}{ Rural } & \multicolumn{3}{|c|}{ Urban } \\
\hline & $n=342$ & FS \% & FI \% & $n=198$ & FS \% & $\mathrm{Fl} \%$ & $n=144$ & FS \% & $\mathrm{Fl} \%$ \\
\hline \multicolumn{10}{|l|}{ Gender of family head } \\
\hline Male & 160 & 15.6 & 84.4 & 91 & 15.4 & 84.6 & 69 & 15.9 & 84.1 \\
\hline Female & 182 & 16.5 & 83.5 & 107 & 15.9 & 84.1 & 75 & 17.3 & 82.7 \\
\hline Income & & ** & & & + & & & + & \\
\hline$<1 \mathrm{MW}$ & 231 & 12.6 & 87.4 & 142 & 12.7 & 87.3 & 89 & 12.4 & 87.6 \\
\hline$\geq 1 \mathrm{MW}$ & 111 & 23.4 & 76.6 & 56 & 23.2 & 76.8 & 55 & 23.6 & 76.4 \\
\hline \multicolumn{10}{|l|}{ Income transfer programs } \\
\hline Yes & 274 & 15.3 & 84.7 & 160 & 14.4 & 85.6 & 114 & 16.7 & 83.3 \\
\hline No & 68 & 19.1 & 80.9 & 37 & 21.6 & 78.4 & 31 & 16.1 & 83.9 \\
\hline Educational level of family head & & & & & & & & * & \\
\hline Illiterate & 78 & 10.3 & 89.7 & 56 & 14.3 & 85.7 & 22 & 0.0 & 100.0 \\
\hline Incomplete elementary school & 192 & 16.7 & 83.3 & 110 & 17.3 & 82.7 & 82 & 15.9 & 84.1 \\
\hline Full high school or more & 72 & 20.8 & 79.2 & 32 & 12.5 & 87.5 & 40 & 27.5 & 72.5 \\
\hline Type of housing & & & & & & & & * & \\
\hline Masonry & 286 & 15.0 & 85.0 & 160 & 15.6 & 84.4 & 126 & 14.3 & 85.7 \\
\hline Other type & 56 & 21.4 & 78.6 & 38 & 15.8 & 84.2 & 18 & 33.3 & 66.7 \\
\hline \multicolumn{10}{|l|}{ Garbage collection } \\
\hline Public & 281 & 16.4 & 83.6 & 155 & 16.1 & 83.9 & 126 & 16.7 & 83.3 \\
\hline Other & 60 & 15.0 & 85.0 & 42 & 14.3 & 85.7 & 18 & 16.7 & 83.3 \\
\hline \multicolumn{10}{|l|}{ Water supply } \\
\hline Public network & 248 & 17.3 & 82.7 & 111 & 17.1 & 82.9 & 137 & 17.5 & 82.5 \\
\hline Other system & 94 & 12.8 & 87.2 & 87 & 13.8 & 86.2 & 07 & 0.0 & 100.0 \\
\hline Water consumption & & $\star * *$ & & & ** & & & ** & \\
\hline Treated, bottled and boiled & 104 & 28.8 & 71.2 & 55 & 27.3 & 72.7 & 49 & 30.6 & 69.4 \\
\hline Tap water & 238 & 10.5 & 89.5 & 143 & 11.2 & 88.8 & 95 & 9.5 & 90.5 \\
\hline Sewage system & & & & & & & & + & \\
\hline Public network & 90 & 18.9 & 81.1 & 43 & 11.6 & 88.4 & 47 & 25.5 & 74.5 \\
\hline Other system & 252 & 15.1 & 84.9 & 155 & 16.8 & 83.2 & 97 & 12.4 & 87.6 \\
\hline
\end{tabular}

Note: ${ }^{\dagger} p \leq 0.10 ;{ }^{*} p \leq 0.05 ;{ }^{* *} p \leq 0.01 ;{ }^{* * *} p \leq 0.001$.

FS: Food Security; FI: Food Insecurity; MV: Minimun Wage.

insecurity, unlike households that consume untreated water in both rural and urban areas $(p \leq 0.01)$. Regarding the type of housing in the urban area, the lowest percentage of food insecurity occurred in households with worst construction conditions (mud, canvas and other materials), which seems a contradictory situation, probably due to the small number of households in this condition (16\%).

Most of the families receive financial resources from government income transfer programs, with more than $80 \%$ of families living in urban and rural areas of Picos (PI) receiving these resources.

The dietary intake of students for the total sample (Figure 2) showed no statistically significant difference with respect to food insecurity, the same occurring for rural and urban areas (data not shown).

Considering the foods analyzed, it was observed that the most consumed foods are cereals, sugars and fats. Roots, eggs, miscellaneous (ice cream, soft drinks, processed juices) and vegetables in this order are among 
Table 2. Nutritional profile of schoolchildren according to the food insecurity classification and place of residence, Picos (PI), 2009.

\begin{tabular}{|c|c|c|c|c|c|c|c|c|c|}
\hline \multirow{2}{*}{ Anthropometric variables } & \multicolumn{3}{|c|}{ Total } & \multicolumn{3}{|c|}{ Rural } & \multicolumn{3}{|c|}{ Urban } \\
\hline & $n=342$ & FS \% & $\mathrm{FI} \%$ & $n=198$ & FS \% & $\mathrm{Fl} \%$ & $n=144$ & FS \% & $\mathrm{Fl} \%$ \\
\hline \multicolumn{10}{|l|}{ BMllage* } \\
\hline Low weight & 14 & 3.6 & 4.2 & 7 & 3.2 & 3.6 & 7 & 4.2 & 5.0 \\
\hline Normal weight & 289 & 85.5 & 84.3 & 168 & 87.1 & 84.4 & 121 & 83.3 & 84.2 \\
\hline Overweight & 39 & 10.9 & 11.5 & 23 & 9.7 & 12.0 & 16 & 12.5 & 10.8 \\
\hline \multicolumn{10}{|l|}{ Weight/age* } \\
\hline Weight deficit & 21 & 9.1 & 5.9 & 11 & 9.7 & 5.0 & 10 & 8.3 & 7.1 \\
\hline Normal weight & 307 & 90.9 & 94.1 & 180 & 90.3 & 95.0 & 127 & 91.7 & 92.9 \\
\hline \multicolumn{10}{|l|}{ Height/age* } \\
\hline Height deficit & $14(4.1)$ & 5.5 & 3.8 & 7 & 3.2 & 3.6 & 7 & 8.3 & 4.2 \\
\hline Normal height & $328(95.9)$ & 94.5 & 96.2 & 191 & 96.8 & 96.4 & 137 & 91.7 & 95.8 \\
\hline
\end{tabular}

Note: ${ }^{*} p<0.05$

FS: Food Security; FI: Food Insecurity; BMI: Body Mass Index.

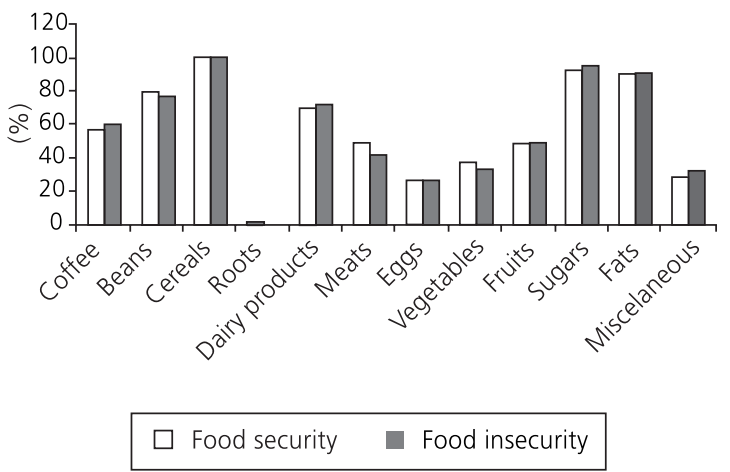

Figure 2. Food consumed by schoolchildren ( $n=342)$ at least once a day, according to food insecurity. Picos (PI), 2009.

Note: $p<0.05$.

the less consumed foods by schoolchildren. Among the protein sources, beans and dairy products are more consumed than meats and eggs. High consumption of coffee and beans was observed, exceeding $56 \%$ and $75 \%$, respectively. However, less than $50 \%$ of children consume fruits and vegetables at least once a day. Regarding the study outcome, children at food security consume a little more meat and vegetables than children at food insecurity, although without significant differences.

Table 2 shows that there was no statistical difference for anthropometric indicators of schoolchildren living in rural and urban areas, either when associated with food insecurity, probably due to the low prevalence of anthropometric deficit with values between $6.4 \%$ and $4.1 \%$.

\section{DISCUSSION}

In the present study, no difference was observed in the prevalence of food insecurity among families with children living in urban and rural areas of Picos (PI). However, the percentages of the most severe forms of food insecurity were higher than the average for families with children under 18 years of age in the state of Piauí, which was $10.6 \%$ for moderate food insecurity and $6.9 \%$ for severe food insecurity in the urban area, and 15.9 and $10.7 \%$ in rural areas. Similarly, moderate and severe food insecurity was higher than the average found for children aged 4 to 7 and 8 to 10 years, of $26.9 \%$ and $18.8 \%$, respectively, in the state of Piauín ${ }^{2}$.

According to the 2004-2009 National Household Survey ${ }^{12}$, in northern and northeastern Brazil, severe food insecurity showed higher proportions in the rural area, while in southern and Midwestern Brazil, the inverse occurred, where severe food insecurity was detected in higher proportions in urban areas. Yuyama et al. ${ }^{11}$ 
found that families living in the urban area of Manaus (AM) had higher prevalence of food insecurity compared to those living in rural areas. In a study conducted by the United States Departament of Agriculture, highest prevalence of food insecurity was detected in large cities and in rural areas ${ }^{17}$, since individual perception of food insecurity and socioeconomic indicators play an important role, regardless of place of residence, whether rural or urban? .

Similarity in the prevalence of food insecurity of families living in urban and rural areas of Picos (PI) with income less than 1 minimum wage $(87.3$ to $87.6 \%)$, near $85.4 \%$, was observed, which corroborates the results by Yuyama et al. ${ }^{11}$ for families living in the urban area of Manaus (AM) with income less than 1 minimum wage.

In the present study, low income and low educational level of the family head were associated with higher prevalence of food insecurity. According to Sales-Costa et al. ${ }^{18}$, income and education are determinants of food insecurity, since low family income and educational level significantly contribute to increasing food insecurity, as well as the availability of treated water and sewage system, since they are associated with the provision of basic public services.

In a study conducted in Duque de Caxias (RJ), sanitary conditions were not associated with perception of food insecurity; however, the consumption of treated water was positively associated with food security ${ }^{18}$, which result is similar to the present study, in which the consumption of treated, bottled or boiled water, whether in urban or rural areas, was decisive and significantly higher $(p \leq 0.01)$ among families in food security.

Government income transfer programs were not able to influence the income of these families, and most of them have monthly income less than one minimum wage. According to the 2004 National Household Survey ${ }^{12}$, levels of food insecurity - mild, moderate or severe - affected $66 \%$ of families with at least one beneficiary of government income transfer programs, and the authors claim that there is a relevant contribution of income transfer programs to reduced inequality, poverty alleviation and improvement of social conditions of the population. However, according to Anschau et al. ${ }^{19}$, the high prevalence of food insecurity among beneficiaries of income transfer programs as compared to nonbeneficiaries of the same social stratum indicates the need for better understanding the circumstances that characterize the lives of those families.

Regarding food consumption in Picos (PI), vegetables and meats were the most sensitive to food insecurity in urban or rural areas, although without statistical significance. Different result was observed by Yuyama et al. ${ }^{11}$ in the Amazon region, where rural riverside families consume more grains, fruits, vegetables, roots, oil and meat than families living in urban areas. According to Segall-Côrrea ${ }^{3}$ and Panigassi et al. ${ }^{20}$, as food insecurity conditions are more severe, the consumption of fruits, vegetables, meats, and dairy products is lower, and this behavior is uniform in all Brazilian regions, except for the Amazon region, where hunting, fishing and collection of regional fruits increase the food availability.

In a study by D'Innocenzo et al. ${ }^{21}$ with children aged 4-11 years, it was observed that dietary patterns of children are dependent on the socioeconomic conditions of their families, and the adoption of healthier food items is associated with higher socioeconomic status, because the lower the socioeconomic level, the more fried foods, sweets, snacks and soft drinks/artificial juice and less fruits, legumes, vegetables, fish and cereals are consumed by children. Moreover, Triches \& Giugliane ${ }^{22}$ highlight that there is a recent and excessive marketing of a variety of foods high in energy and fat, affordable and available to schoolchildren. On the other hand, foods such as vegetables and fruits with less energy and more nutritional value are increasingly lacking in children's diets. 
The study by Conceição et al. ${ }^{23}$ with children aged 9-16 years enrolled in private and public schools in the state of Maranhão also found high consumption of sugar and sweets (69.4\%) and oils and fats (65.6\%); however, the consumption of this food group by schoolchildren evaluated here was even higher, with more than $89.0 \%$ consuming oils and fats and $92.0 \%$ consuming sugars and sweets at least once a day.

Similar results were obtained by Antunes et al. ${ }^{24}$, in which children under 3 years at food insecurity showed high consumption of coffee, being higher among children with the most severe forms of food insecurity. Antunes et al. ${ }^{24}$ also observed that the consumption of fruits, vegetables, and dairy products was below recommendations for children in situation of food security or insecurity.

It is noteworthy that some foods cannot be consumed due to various reasons such as unpleasant taste, difficulty of finding food; difficulty in eating; price; not having the habit or time to eat ${ }^{25}$, moreover, one should take into account the limitations of methodologies for measuring food consumption in line with food insecurity ${ }^{8}$.

The population of students living in rural or urban areas of Picos (PI) was fairly homogeneous regarding anthropometry, with similarities in the forms of malnutrition (deficits and excesses) for most students, despite the condition of food insecurity largely shown by the families of these children. Segall-Corrêa ${ }^{3}$ explained that the anthropometric measure is an important indicator of nutritional status; however, it assesses food insecurity indirectly, and eventually obtains normal values for weight, height and Body Mass Index (BMI) in families in situation of food insecurity. Accordingly, Oliveira et al. ${ }^{26}$ reported that in populations with high levels of poverty, low Human Development Index and high prevalence of food insecurity, the exclusive use of anthropometric indicators may reveal a situation apparently quite more favorable than reality.
Some studies suggest a relationship between obesity and food insecurity and claim that food insecurity does not increase the chances of being overweight in childhood; however, they may increase in adulthood ${ }^{27}$ and others that suggest an association between malnutrition and food insecurity ${ }^{7}$ discuss that these relationships are directly related to differences in dietary patterns that may exist among children in conditions of food insecurity, as many high-calorie foods cost less than healthier ones.

According to Oliveira \& Lima Filho ${ }^{28}$ malnutrition and obesity often coincide in families with food and nutrition insecurity, causing the average amplitude of BMI of families increase according to food insecurity, considering that food security levels positively impact anthropometric indexes.

The study by Pellegrini et al. ${ }^{29}$ with schoolchildren aged 10-17 years enrolled in public schools in the states of Santa Catarina and Rio Grande do Sul showed higher percentage of normal weight children (82.3\%) and lower percentage of overweight students $(6.7 \%)$ in urban areas, with $11.0-11.7 \%$ of malnourished children living in rural and urban areas, with no statistical difference for this nutritional status among students of different places of residence. This result is quite similar to that found in the present study, in which schoolchildren living in rural areas showed nutritional status similar to those living in urban areas.

Among the limitations of this study, there is the possibility of one-off factors or short-term view of the Food and Nutrition Security by the interviewee and the subjective aspects of the applied scale. The sample is only representative for students and not necessarily for the urban and rural areas. In populations of less developed regions and small and medium-sized cities, complex conditions such as the perception of food insecurity may be uniform across different socioeconomic strata. 


\section{CONCLUSION}

The prevalence of food insecurity was similar between urban and rural areas in the city of Picos (PI). Among associated factors, low family income and consumption of untreated water contributed to the higher percentage of families in conditions of food insecurity.

Dietary intake and nutritional status of schoolchildren were not associated with the condition of food insecurity among students. Further studies should be carried out to better characterize the population at food insecurity, taking into account the constant changes in the socioeconomic and environmental conditions, food habit and lifestyle of the population, and the development and implementation of public policies in the field of food and nutrition.

\section{A C KNOWLEDGMENTS}

To the Department of Education of the City of Picos (PI) and the Universidade Federal do Piauí for logistical support, and the children and parents who voluntarily participated in this study. To Conselho Nacional de Desenvolvimento Científico e Tecnológico for the productivity scholarship to Pedro Israel Cabral de Lira.

\section{CONTRIBUTORS}

IS AQUINO conducted the collection and interpretation of data, drafting of the manuscript. LAS SIQUEIRA-DE-ANDRADE conducted the statistical analysis and critical revision of the manuscript. PEB ALENCAR DA SILVA conducted the collection and tabulation of data. AP SILVA conducted the collection and tabulation of data. CRS VIEIRA conducted the collection and tabulation of data. drafting of the manuscript. PIC LIRA conducted the statistical analysis, drafting and critical revision of the manuscript.

\section{REFEREN CES}

1. Conselho Nacional de Segurança Alimentar e Nutricional. Documento base: $3^{a}$ Conferência Na- cional de Segurança Alimentar e Nutricional. Brasília: Consea; 2007.

2. Brasil. Ministério das Relações Exteriores. A segurança alimentar e nutricional e o direito humano à alimentação no Brasil. Brasília: Ipea; 2002.

3. Segall-Corrêa AM. Insegurança alimentar medida a partir da percepção das pessoas. Estud Av. 2007; 21(60):143-54. doi: 10.1590/S0103-401420070 00200012

4. Kepple AW, Segall-Corrêa AM. Conceituando e medindo segurança alimentar e nutricional. Ciênc Saúde Colet. 2011; 16(1):187-99. doi: 10.1590/ S1413-81232011000100022

5. Kuku O, Gundersen C, Garasky S. Differences in food insecurity between adults and children in Zimbabwe. Food Policy. 2011; 36(2):311-7. doi: 10.1016/j.foodpol.2010.11.029

6. Cruz GF, Santos RS, Carvalho CMRG, Moita GC. Avaliação dietética em creches municipais de Teresina, Piauí, Brasil. Rev Nutr. 2001; 14(1):21-32. doi: 10.1590/S1415-52732001000100004

7. Gray VB, Cossman JS, Powers EL. Stunted growth is associated with physical indicators of malnutrition but not food insecurity among rural school children in Honduras. Nutr Res. 2006; 26(11):549-55. doi: 10.1016/j.nutres.2006.09.009

8. Champagne CM, Casey PH, Connel CL, Stuff JE, Gosset JM, Harsha DW, et al. Poverty and food intake in rural America: Diet quality is lower in food insecure adults in the Mississippi delta. J Am Diet Assoc. 2007; 107(11):1886-94. doi: 10.1016/ j.jada.2007.08.003

9. Dean WR, Sharkey JR. Food insecurity, social capital and perceived personal disparity in a predominantly rural region of Texas: An individual-level analysis. Soc Sci Med. 2011; 72(9):1454-62. doi: 10.1016/ j.socscimed.2011.03.015

10. Jensen L, McLaughlin DK, Slack T. Rural poverty: The persisting challenge. Challenges for rural America in the twenty-first century. University Park (PA): Pennsylvania State University; 2003.

11. Yuyama LKO, Aguiar JPL, Pantoja L, Maeda RN, Melo T, Alencar FH, et al. Segurança/insegurança alimentar em famílias urbanas e rurais no estado do Amazonas: I. Validação de metodologia e de instrumento de coleta de informação. Acta Amaz. 2007; 37(2):247-52. doi: 10.1590/S0044-59672 007000200011

12. Instituto Brasileiro de Geografia e Estatística. Pesquisa nacional de amostra de domicílios: segurança alimentar 2004-2009. Rio de Janeiro: IBGE; 2010.

13. Instituto Brasileiro de Geografia e Estatística. Censo 2010. Rio de Janeiro: IBGE; 2010 [acesso 2010 set 12]. Disponível em: <http://www.ibge.gov.br/ cidadesat/topwindow.htm?1>. 
14. Segall-Corrêa AM, Perez-Escamilla R, Marin-Leon L, Sampaio MFA, Panigassi G, Maranha LK. Acompanhamento e avaliação da Segurança Alimentar de famílias brasileiras: validação de metodologia e de instrumento de coleta de informação (urbano/rural): relatório técnico. Campinas: Unicamp; 2004.

15. Cintra IP, Von Der Heyde MED, Schmitz BA, Franceschini SCC, Taddei JA, Sigulem DM. Métodos de inquéritos dietéticos. Cad Nutr. 1997; 13:11-23.

16. Lohman TG, Roche AF, Martorell R. Anthropometrics standardization reference manual. Champaign (IL): Human Kinetics Books; 1988.

17. World Health Organization. Anthro for personal computers. Version 2, 2007: Software for assessing growth and development of the world's children. Geneva: WHO; 2007 [cited 2011 Feb 20]. Available from: <http://www.who.int/childgrowth/software/ en/>.

18. Salles-Costa R, Pereira RA, Vasconcellos MTL, Veiga GV, Marins VMR, Jardim BC, et al. Associação entre fatores socioeconômicos e insegurança alimentar: estudo de base populacional na região metropolitana do Rio de Janeiro, Brasil. Rev Nutr. 2008; 21(Suppl):99-109.

19. Anschau FR, Matsuo T, Segall-Côrrea AM. Insegurança alimentar entre beneficiários de programas de transferência de renda. Rev Nutr. 2012; 25(2):177-89. doi: 10.1590/S1415-52732012000200001

20. Panigassi G, Segall-Correa AM, Marin-Leòn L, Pèrez-Escamilla R, Maranha LK, Sampaio MFA. Insegurança alimentar intrafamiliar e perfil de consumo de alimentos. Rev Nutr. 2008; 21(Suppl 1):S135-44. doi: 10.1590/S1415-52732008000700012

21. D'Innocenzo S, Marchioni DML, Prado MS, Matos SMA, Pereira SRS, Barros AP, et al. Condições socioeconômicas e padrões alimentares de crianças de 4 a 11 anos: estudo SCAALA - Salvador/Bahia. Rev Bras Saúde Mater Infant. 2011; 11(1):41-9. doi: 10.1590/S1519-38292011000100005
22. Triches RM, Giugliane ERJ. Obesidade, práticas alimentares e conhecimentos de nutrição em escolares. Rev Saúde Pública. 2005; 39(4):541-7.

23. Conceição SIO, Santos CJN, Silva AAM, Silva JS, Oliveira TC. Consumo alimentar de escolares das redes pública e privada de ensino em São Luís, Maranhão. Rev Nutr. 2010; 23(6):993-1004. doi: 10.1590/S1415-52732010000600006

24. Antunes MML, Schieri R, Salles-Costa R. Consumo alimentar de crianças menores de três anos residentes em área de alta prevalência de insegurança alimentar domiciliar. Cad Saúde Pública. 2010; 26(8):1642-50. doi: 10.1590/S0102-311X2010 000800017

25. Salles-Costa R. Avaliação alimentar em Duque de Caxias (RJ). Estud Av. 2007; 21(60):135-42.

26. Oliveira JO, Lira PIC, Andrade SLLS, Sales AC, Maia SR, Batista Filho M. Insegurança alimentar e estado nutricional de crianças de São João do Tigre, no Semi Árido do Nordeste. Rev Bras Epidemiol. 2009; 12(3):413-23. doi: 10.1590/\$1415-790X2009000 300010

27. Mantin KS, Ferris AM. Food insecurity and gender are risk factors for obesity. J Nutr Educ Behav. 2007; 39:31-6. doi: 10.1016/j.jneb.2006.08.021

28. Oliveira LDS, Lima Filho DO. Modelo de segurança alimentar e nutricional e seus determinantes socioeconômicos e comportamentais. Cad Gestão Pública Cid. 2011; 16(59):1-20.

29. Pelegrini A, Silva DAS, Petroski EL, Glaner MF. Estado nutricional e fatores associados em escolares domiciliados na área rural e urbana. Rev Nutr. 2010; 23(5):839-46. doi: 10.1590/S1415-527320100 00500014
Received on: 9/27/2013

Final version on: 5/30/2014 Approved on: 6/25/2014 